Global Conferences Series:

Social Sciences, Education and Humanities (GCSSSEH), Volume 6, 2020

International Conference Fakultas Tarbiyah dan Keguruan Universitas Islam Negeri Imam Bonjol Padang (ICFTKUINIBP) 2020

DOI: https://doi.org/10.32698/icftk390

\title{
Merdeka Belajar from the Perspective of Family Education
}

\author{
Mardeka Belajar dalam Perspektif Pendidikan Keluarga
}

\author{
Teguh Widodo $^{\text {a }}$, Duski Samad ${ }^{\text {b }}$, Muhammad Kosim ${ }^{\text {b }}$, Suryadi Fajri ${ }^{\text {b }}$, Fatmi Fauzani Duski ${ }^{\mathrm{c}}$ \\ ${ }^{a}$ Badan Kependudukan dan Keluarga Berencana Nasional, Padang, Indonesia, ${ }^{b}$ Universitas Islam Negeri \\ Iman Bonjol, Padang, Indonesia, ${ }^{c}$ Universitas Negeri Padang, Indonesia \\ E-mail: t29uhw@yahoo.co.id
}

\begin{abstract}
There are many letters in the Qur'an and hadith that support the learning process. The phenomenon that has surfaced at this time is the emergence of freedom in learning as a government policy that is applied to students. Learning is actually an educational process that one must go through in gaining knowledge. The problem of how to learn to get knowledge, there will be many ways-and that's the art of learning. Free learning may be an approach or method for their students in gaining knowledge. Likewise, independent learning is a new method or approach for a student in gaining knowledge. Freedom in learning is a learning perspective that must be adapted by both teachers and students in the current era, because it has become a policy. However, one thing that needs to be understood in the concept of education is that independent learning must also be adapted by the family, because after students return from school, of course further education becomes the authority of the parents. The question is in how to apply independent learning from a family perspective? What conditions should be met in the family when freedom of learning is applied?. This article tries to answer these two big questions by first explaining the concept of learning itself. Furthermore, the concept of family and its function in education is explained. The next discussion is about the application of freedom in learning of the family educational perspective and the last discussion is family resilience as a pillar in the freedom in learning approach in Indonesia.
\end{abstract}

Keywords: Freedom in learning, family function and family resilience

\section{INTRODUCTION}

Merdeka Belajar sebagai kebijakan baru Kementerian Pendidikan dan Kebudayaan Republik Indonesia saat ini menuai pro dan kontra (Priatmoko \& Dzakiyyah, 2020). Layaknya sebuah perubahan, awalnya menuai protes, namun dalam prosesnya banyak mengalami adaptasi dan improvisasi bahkan kompromi. Namun akhirnya perubahan itu sendiri lambat laun akan diterima (Kadi \& Awwaliyah, 2017). Demikian halnya dengan kebijakan merdeka belajar itu sendiri. Esensi kemerdekaan berpikir itu yang menjadi cikal bakal munculnya merdeka belajar (Mastuti et al., 2020).

Hakikat belajar dalam Islam sejatinya tersurat dalam Qur'an dan hadist cukup banyak di antaranya QS Al-Alaq/96 (1-5), Al-Baqarah/2 (31), QS An-Nahl/16 (78), Luqman/31 (17-19). Sedangkan hadist shohih

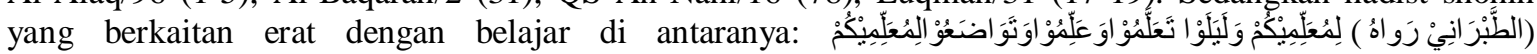
"Belajarlah kamu semua, dan mengajarlah kamu semua, dan hormatilah guru-gurumu, serta berlaku baiklah

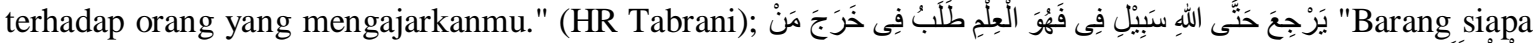

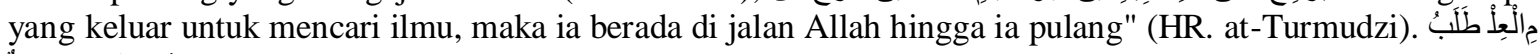
مُسنلِ كُلِّ عَلَى فَرِيْضَةُّ (Menuntut ilmu itu wajib atas setiap Muslim” (HR. Ibnu Majah no. 224)

Belajar sejatinya merupakan proses pendidikan yang harus dilalui oleh seseorang dalam mendapatkan ilmu (Nata, 2014). Persoalan bagaimana cara belajar untuk mendapatkan ilmu, maka akan ada banyak cara

Copyright $@ 2020$, the Authors. Published by Redwhite Press. 
dan itulah seninya belajar. Boleh jadi merdeka belajar menjadi sebuah pendekatan ataupun metode bagi anak didiknya dalam mendapatkan ilmu.

Terlepas dari pro dan kontra terhadap kebijakan dimaksud, merdeka belajar merupakan perspektif pembelajaran yang harus diadaptasi baik oleh guru maupun murid di era saat ini, karena hal tersebut sudah menjadi kebijakan. Namun satu hal yang perlu pahami dalam konsep pendidikan adalah, bahwasannya merdeka belajar juga harus diadaptasi oleh keluarga, karena setelah siswa pulang sekolah, tentunya pendidikan selanjutnya menjadi kewenangan orang tua. Bahkan Islam mengajarkan bahwa orang tua institusi pertama yang berkewajiban mendidik anak-anaknya (Usman, 2017). Pertanyaannya adalah dalam bagaimana penerapan merdeka belajar dalam perspektif keluarga? Kondisi seperti apa yang hendaknya dipenuhi dalam keluarga ketika merdeka belajar diterapkan.

Artikel ini mencoba menjawab dua pertanyaan besar tersebut dengan terlebih dahulu menjabarkan konsep belajar itu sendiri. Selanjutnya dijelaskan konsep keluarga dan fungsinya dalam pendidikan. Bahasan berikutnya mengenai Penerapan Merdeka dalam Perspektif Keluarga dan bahasan terakhir adalah Ketahanan Keluarga sebagai Pilar dalam Pendekatan Merdeka Belajar di Indonesia.

\section{METODE}

Penelitian ini menggunakan jenis penelitian library research yakni penelitian yang dilakukan melalui pengumpulan data atau karya tulis Ilmiah yang bertujuan untuk memecahkan suatu masalah. Pada dasarnya penelitian kepustakaan itu termasuk kategori penelitian kualitatif, karena terdapatnya kepentingan terhadap penafsiran dan mencari makna dari teks-teks tertulis (Suyanto, 2015). Penelitian kepustakaan mengarahkan penelitiannya pada pengkajian dan penelusuran ide-ide dan khasanah pemikiran pada sumber-sumber kepustakaan seperti naskah-naskah, karya tulis dan lain sebagainya (Sutrisno, 2000). Jadi, untuk meneliti konsep merdeka belajar dalam perspektif keluarga ini dianalisis dengan menggunakan sumber tertulis dari karya tulis yang relevan.

Dalam memahami dan menafsirkan serta memaknai literatur dan teks, digunakan pendekatan hermeneutik. Urgensi pendekatan hermeneutik dalam penelitian adalah sebagai upaya memahami makna teks (kitab suci, buku, undang-undang dan lainnya) yang berfungsi untuk menghindari agar tidak terjadi distorsi pesan atau informasi antara penulis teks dan pembaca teks (Suprayogo \& Tobroni, 2001).

Di dalam pengolahan dan penganalisaan semua data dari literatur serta teks, digunakan metode content analysis (Suprayogo \& Tobroni, 2001). Metode content analysis di dalam mengukur tingkat akurasi dan proses penarikan kesimpulan terhadap pesan, setidaknya memiliki tiga langkah yang dapat dilakukan, yaitu deskriptif, analisis isi secara kritis, dan korelatif. Secara umum, proses pengolahan data dalam sebuah penelitian dapat juga dikelompokkan kepada tiga tahapan yang meliputi: pertama, aktivitas pengumpulan data dari referensi-referensi kajian ilmiah yang kemudian mengelompokkannya dan mendeskripsikannya; kedua, kegiatan analisis data setelah mendeskripsikan konsep-konsep pemikiran, dan ide-ide, kemudian dianalisis dengan menggunakan pisau analisis pola berfikir analitik induktif, deduktif, dan interaktif (paduan dari induktif dengan deduktif); dan ketiga memberikan penafsiran dan pemaknaan terhadap hasil analisis yang bertujuan untuk mengambil kesimpulan-kesimpulan.

\section{RESULT AND DISCUSSION \\ Belajar sebagai Proses Mendapatkan Ilmu}

Proses belajar dan pembelajaran suatu keharusan bagi manusia dalam kehidupan. Berbagai fenomena yang terjadi di alam semesta akan muncul ketika ini dilakukan dengan belajar. Tentu saja, belajar dalam pengertian ini sangat luas, membaca fenomena alam dan realitas sosial sebagaimana diwahyukan kepada nabi Muhammad SAW dalam QS al-Alaq ayat 1-5 (Ramayulis, 2008). Belajar sejatinya bukanlah persaingan mendapatkan nilai tertinggi sebagaimana terjadi pada era saat ini. Belajar yang berorientasi nilai membuat anak didik stress khawatir tidak naik kelas atau tidak diterima di perguruan tinggi-dan kemudian menuntut mereka berpikir pragmatis seperti mencontek, membeli gelar, menggunakan joki dan itu membuat anak menjadi berperilaku kurang beradab. Belajar yang berorientasi pada nilai/prestasi membuat anak didik menjadi berperilaku individualis, seperti autis memikirkan diri sendiri supaya dikatakan pintar.

Belajar merupakan proses mendapatkan pengetahuan sebagaimana telah diajarkannya Nabi Adam mengenal nama-nama benda, seperti yang dijelaskan dalam surat al-Baqarah ayat 31 (Langgulung, 2002). Jadi kalau sekiranya seseorang belum mengetahui tentang sesuatu yang sedang dipelajarinya maka orang yang lebih tahu hendaknya mengajarkannya. Tapi bila belajar diartikan sebuah persaingan, maka orang yang tidak tahu cenderung dibiarkan tidak tahu supaya orang tersebut kalah bersaing. 
Karena belajar merupakan sebuah proses mendapatkan ilmu, di mana kemampuan kognitif termasuk di dalamnya daya tangkap seseorang menyerap ilmu itu berbeda-beda karena setiap orang diberikan anugerah otak yang berbeda pula, maka kemampuan tiap orang akan berbeda-beda. Dalam konteks ini pengajar harus memiliki seni mengajarkan supaya dalam penyerapan ilmu segera masuk ke dalam diri siswa. Persoalannya adalah semakin banyak siswa yang diajar, maka akan semakin banyak cara untuk mengajarkan ilmu dan itu memerlukan waktu lebih lama sehingga kompetensi yang ditargetkan kepada siswa yang jumlahnya banyak menjadi tidak tercapai.

Kembali pada diri siswa didik, bahwasannya selain kemampuan yang berbeda dalam menyerap ilmu, mereka juga memiliki minat yang berbeda dalam mempelajari berbagai jenis ilmu (Syah, 2010). Hal ini tentunya dipengaruhi oleh latar belakang kehidupan siswa itu sendiri dan atau bakatnya. Maka ketika diuji secara prestasi, maka akan ada nilai yang menonjol dan ada yang rendah. Sudah cukup banyak bukti bahwa kesuksesan seseorang di kemudian hari bukan satu-satunya ditentukan oleh prestasi akademis, namun multifaktorial.

Merdeka belajar merupakan sebuah tawaran alternatif kepada siswa supaya kompetensi dalam belajar dapat tercapai dan yang tidak kalah penting adalah men-trigger bakat dalam diri siswa supaya tumbuh sesuai dengan minat dan bakatnya. Dalam arti kata merdeka belajar merupakan bagian dari usaha dalam menciptakan kader manusia berbakat menuju insan kamil. Merdeka belajar sebuah proses kreatifitas metode belajar dengan menggunakan apapun media sebagai sumber pembelajaran (Yamin \& Syahrir, 2020).

Hal yang perlu diwaspadai apalagi di era industri 4.0 di mana segala informasi dan arusnya begitu cepat di tangan manusia tanpa batas. Demikian halnya dengan pengetahuan yang masuk dan terserap oleh siapa saja yang mengakses termasuk siswa. Bahayanya adalah bila siswa belum dibekali dengan nilai-nilai mendasar tentang keagamaan dan perilaku, maka akses informasi yang bisa jadi menjadi metode pembelajaran akan disalahartikan bahkan disalahgunakan. Kemajuan teknologi di era digital akan mempengaruhi karakter anak (Kosim, 2020). Maka menjadi penting kiranya sebelum merdeka belajar diterapkan sebagai metode pembelajaran, siswa secara mendasar dibekali dengan penanaman nilai-nilai dimaksud (keagamaan dan perilaku).

Mengingat secara formal pendidikan dimulai semenjak anak di PAUD atau sejak usia 5-6 tahun, sementara sebelum itu anak normalnya dalam pengasuhan orang tua, tentunya penanaman nilai-nilai dimaksud hendaknya sudah sejak dini. Mengingat pula bahwa pendidikan formal anak maksimal 8 jam dalam sekolah sedangkan sisa waktunya ada pada orang tua dan lingkungan, maka menjadi penting juga orang tua harus terlebih dahulu paham hendaknya menjadi tauladan bagi anak-anaknya dalam beragama dan berperilaku yang baik.

\section{Keluarga sebagai Fungsi Pendidikan}

Salah satu dari 8 fungsi keluarga adalah keluarga berfungsi sebagai wadah dalam mendidik anggota keluarga termasuk anak-anaknya (Handayani et al., 2018). Apa yang dididik dalam keluarga yang paling utama adalah tentang agama, karena fungsi agama dalam keluarga juga ada. Selanjutnya pendidikan dalam hal penanaman norma-norma mulai dari norma individu, keluarga dan bermasyarakat tentunya ditanamkan kepada diri anak. Karena keluarga memiliki fungsi pendidikan, maka sedikit banyak atau lambat laun merdeka belajar juga akan diadopsi sebagai pendekatan dalam mendidik keluarganya. Artinya keluarga juga akan menggunakan segala sumber di dalam upaya mendidik anaknya supaya pengetahuan terserap dalam diri anak itu sendiri.

Prasyarat pendidikan dalam keluarga akan terjadi maksimal bilamana keluarga dalam posisi terjaga keutuhannya, terpelihara keharmonisan antar anggota keluarga dan secara ekonomi terpenuhi kebutuhannya. Dalam arti kata, ketahanan keluarga menjadi prasyarat terlaksananya pendidikan dalam keluarga. Apabila merdeka belajar sebagai pendekatan dalam pendidikan dalam keluarga maka diperlukan usaha yang lebih maksimal lagi dalam menanamkan nilai-nilai dalam keluarga supaya agama yang ditanamkan kepada anak, norma yang diajarkan melalui perilaku dan suritauladan tidak disalahartikan dan disalahtafsirkan.

Dengan demikian, pengetahuan orang tua terhadap agama itu sendiri, filosofi pendidikan dan karakter yang dapat ditauladani banyak, kokoh dan berkualitas. Dengan demikian, penguatan pondasi agama penting dilakukan dalam membentuk ketahanan keluarga melalui proses pendidikan yang benar.

\section{Penerapan Merdeka Belajar dalam Perspektif Keluarga}

Kebijakan merdeka belajar yang digagas oleh Menteri Pendidikan dan Kebudayaan, Nadiem Makarim, lebih menekankan pada kegiatan pembelajaran di lembaga pendidikan formal yang menginginkan terciptanya suasana belajar yang bahagia tanpa dibebani dengan pencapaian skor atau nilai tertentu. Secara esensial, keinginan ini bukanlah hal yang baru dalam dunia pendidikan. Siti Mustaghfiroh menegaskan 
bahwa konsep kebijakan merdeka belajar tersebut relevan dengan konsep pendidikan menurut aliran filsafat progresivisme John Dewey. Keduanya sama-sama menekankan adanya keleluasaan lembaga pendidikan dalam mengekplorasi semaksimal mungkin kemampuan dan potensi yang dimiliki oleh peserta didik yang secara alamiah agar memiliki kemampuan dan potensi yang beragam. Keduanya menginginkan peserta didik harus bebas dan berkembang secara natural; pengalaman langsung adalah rangsangan terbaik dalam pembelajaran; guru harus bisa memandu dan menjadi fasilitator yang baik; lembaga pendidikan harus menjadi laboratorium pendidikan untuk perubahan peserta didik; serta aktivitas di lembaga pendidikan dan di rumah harus dapat dikooperasikan (Mustaghfiroh, 2020).

Namun kebijakan merdeka belajar belum menyentuh pendidikan informal, yaitu keluarga. Padahal keluarga merupakan institusi utama dan pertama dalam mendidik karakter dan kepribadian anak (Kosim et al., 2020). Oleh karena itu, perlu merumuskan konsep dan penerapan merdeka belajar dalam keluarga.

Dengan demikian, ada tiga prinsip utama merdeka belajar dalam perspektif keluarga. Pertama, setiap manusia dibekali dengan fitrah beragama atau kecenderungan pada agama sehingga manusia senantiasa mengabdi pada sesuatu yang dianggapnya memiliki kelebihan dan kesempurnaan (Khasinah, 2013). Maka keluarga bertanggungjawab mendidik anaknya dengan pendidikan agama sedini mungkin. Dalam Islam, orang tua bertanggung jawab penuh mendidik anaknya agar sesuai pada fitrahnya sehingga kelak selamat dunia dan akhirat, bahagia di dunia dan terpelihara dari siksa neraka (Qs. At-Tahrim/66 ayat 6). Maka proses belajar dan pendidikan, baik di tingkat keluarga maupun lembaga formal mesti berbasis Islam. Dalam istilah Naquib al-Attas perlu proses islamisasi, yaitu proses yang lebih bersifat devolution pada keadaan yang asal daripada evolusi di mana manusia sebagai ruh telah sempurna, tetapi manusia ketika terjelma dalam diri jasmani akan menjadi alpa, jahil dan zhâlim terhadap dirinya sendiri sehingga tidak terhindarkan lagi menjadi tidak sempurna. Di sinilah pentingnya pendidikan Islam (Al-Attas, 1981) sehingga manusia tetap pada fitrahnya yang sempurna sebagai makhluk Allah Swt.

Pada prinsip pertama ini, merdeka belajar bukanlah orang tua memberi kebebasan pada anak untuk memilih dan menentukan agamanya. Makna merdeka belajar dalam konteks ini adalah mendidik anak sesuai dengan fitrahnya yang taat pada sang pencipta. Dalam kajian tasawuf, Abu Qasim al-Qusyairi memperkenalkan konsep hurriyah atau "merdeka" sebagai salah satu maqam dalam kitab Risalah Qusyairiyah. Ia menulis, "Ketahuilah, bahwa hakikat kemerdekaan terletak dalam kesempurnaan penghambaan. Jika penghambaannya benar untuk Allah, maka kemerdekaannya bersih dari perbudakan sesuatu yang berubah" (Al-Qusyairi, 2007).

Tegasnya, ketika anak taat pada agama, maka di saat itulah jiwanya merdeka dari belenggu nafsu syahwat yang bertentangan dengan ajaran agama. Di sinilah pentingnya pendidikan agama dalam keluarga dengan tauhid sebagai pondasi utama. Mengumandangkan adzan di telinga bayi saat lahir mengandung hikmah agar anak dididik dengan pendidikan tauhid sebagai proses belajar pertama dan utama di dunia ini. Bahkan saat anak sudah mampu berpikir, Luqman menegaskan agar anaknya tidak berbuat syirik, tetapi hanya menyembah Allah semata (Surat Luqman/31 ayat 13).

Kedua, mendidik anak dengan memperhatikan potensi dan kelebihan yang dimilikinya. Pendidikan agama dengan mentauhidkan Allah swt tidak bisa ditawar-tawar, mesti dididik oleh orang tua dengan berbagai pendekatan yang mendidik. Namun bidang keilmuan apa yang harus dimiliki dan dikuasai oleh anak secara spesifik tentulah diberikan kebebasan pada anak. Dalam hal ini, merdeka belajar mengandung makna memberikan kebebasan pada anak untuk memilih bidang keilmuan atau jurusan apa yang harus ia geluti. Orang tua harus menyadari bahwa setiap anak memiliki keunikan masing-masing. Dalam teori kecerdasan majemuk, misalnya, Howard Gardner menegaskan ada sembilan kecerdasan manusia, yaitu kecerdasan linguistik, matematis-logis, musikal, kinestetik, interpersonal, intrapersonal, naturalis, dan eksistensial (Syarifah, 2019). Namun masing-masing anak tidak memiliki tingkat kecerdasan yang sama. Ada yang lebih menonjol pada kecerdasan linguistik, ada pula lebih menonjol kecerdasan interpersonal, atau kecerdasan eksistensial, dan seterusnya. Anak juga memiliki bakat dan minat yang berbeda. Maka orang tua perlu mendeteksi sejak dini kecenderungan bakat dan minat serta kecerdasan yang menonjol dari anak-anaknya sehingga pendidikan yang diberikan disesuaikan dengan potensi yang dimilikinya. Lagi-lagi, potensi fitrah sebagai dimensi utama tidak boleh terabaikan.

Ketiga, menciptakan suasana belajar di rumah, sekolah, dan masyarakat. Keluarga bukan saja tempat berteduh dan berkumpul antar anggota keluarga. Namun keluarga juga berfungsi sebagai lembaga pendidikan. Keluarga sejatinya didesain laksana sekolah (madrasah) yang memiliki kurikulum tersendiri, baik terkait dengan tujuan, materi, hingga metode pembelajaran yang dilakukan. Ayah bertindak sebagai leader sekaligus guru, ibu sebagai guru kelasnya. Tujuan utama adalah mendidik anak agar tumbuh dan berkembang sesuai dengan fitrahnya serta mampu mengemban tugasnya sebagai Abdullah (hamba Allah) dan khalifah di muka bumi. Maka orang tua harus mendidik anaknya dengan pendekatan keteladanan, 
pembiasaan, dan nasehat-nasehat agar anak mampu mewujudkan tujuan tertinggi pendidikan, yaitu terbentuknya al-insan al-kamil (Ramayulis, 2008). Untuk mewujudkannya, orang tua mesti menciptakan suasana belajar yang nyaman di rumah, tidak saja kenyamanan dalam bentuk fisik tetapi yang terpenting adalah perhatian dan kasih sayang yang diberikan. Keluarga harmonis menjadi prasyarat untuk menerapkan merdeka belajar di rumah tangga.

Di samping itu, orang tua tentu memiliki keterbatasan dalam mendidik anak. Apalagi dalam mengajarkan ilmu pengetahuan yang beragam. Dalam hal ini, orang tua mesti bermitra dengan guru di sekolah/madrasah sebagai lembaga pendidikan formal. Kebijakan merdeka belajar yang yang diterapkan di lembaga pendidikan formal tersebut mesti didukung oleh orang tua selagi tidak bertentangan dengan prinsipprinsip sebelumnya. Begitu juga dengan keterlibatan masyarakat dibutuhkan dalam menerapkan konsep merdeka belajar. Tanpa dukungan masyarakat yang berpihak pada nilai-nilai agama dan budaya yang benar, maka kepribadian anak bisa menyimpang karena salah memahami arti "merdeka" sebagai perilaku bebas tanpa batas.

Untuk mewujudkan suasana belajar yang dimulai dari keluarga lalu orang tua pro aktif mendukung sekolah/madrasah mengembangkan kebijakan merdeka belajar serta terlibat langsung di tengah-tengah masyarakat dalam mewujudkan lingkungan yang aman, nyaman, dan kondusif sehingga peserta didik berkembang sesuai dengan fitrah dan potensi yang dimilikinya. Dalam konteks ini, maka setiap anggota keluarga mesti mewujudkan ketahanan keluarga sesuai dengan peran dan fungsinya masing-masing, baik ayah, ibu, maupun anak itu sendiri sesuai dengan petunjuk agama (Hisyam et al., 2019). Karena itulah ketahanan keluarga merupakan pilar utama dalam menerapkan merdeka belajar di Indonesia.

\section{SIMPULAN}

Bahwa ketahanan keluarga adalah pilar pokok untuk suksesnya merdeka belajar. Keluarga hendaknya memiliki pondasi kuat dalam hal aqidah sehingga anak yang belajar dengan banyak sumber akan ada dalam ikatan tauhid. Namun bila ini pondasi ini belum dimiliki oleh keluarga terutama orang tua, maka hendaknya secara sukarela boarding school menjadi alternatif penanaman akidah itu sendiri.

Sebagai catatan penutup, merdeka belajar merupakan alternatif pendekatan pembelajaran yang saat ini bergulir dan menjadi kebijakan nasional. Tentunya sebagai warga negara yang baik dan memiliki daya filter terhadap diri keluarga, maka berpulang pada masing-masing keluarga. Bila keluarga akan tetap menurunkan agama orang tua kepada agama anaknya, maka pondasi tauhid orang tua harus kuat terlebih dahulu supaya ketika anak menafsirkan apa yang dipahaminya dari berbagai sumber pengetahuan memiliki daya saring dan daya kritik yang baik. Demikian halnya, bila keluarga akan tetap menurunkan norma-norma dan ahlakul karimah keluarga menjadi norma dan ahlak yang baik dalam masyarakat, maka norma dan moral keluarga terlebih dahulu harus diinternalisasi secara utuh terlebih dahulu sebelum didominasi oleh norma masyarakat yang kadangkala mulai bergeser ke arah longgarnya toleransi sehingga memudahkan norma yang tidak baik masuk dalam masyarakat. Sebagai contoh, karena agama merupakan kebebasan orang untuk memeluk agama apapun yang diakui negara, maka apapun agama yang dipeluk dalam anggota keluarga tersebut tidaklah perlu dipertentangkan. Sekilas pintas, kebebasan beragama setiap individu dianggap baik di mata negara karena itu mencerminkan toleransi dan hak asasi manusia, tapi sejatinya itu menunjukkan kerapuhan dalam keluarga dalam menanamkan nilai-nilai ketauhidan beragama.

\section{REFERENSI}

Al-Attas, S. M. N. (1981). Islam dan Sekularisme, terj. Bandung: Pustaka.

Al-Qusyairi, A. Q. (2007). Risalah Qusyairiyah: Sumber Kajian Ilmu Tasawuf (2nd ed.). Pustaka Amani.

Handayani, A., Yulianti, P. D., \& Ardini, S. N. (2018). Membina Keluarga Sejahtera Melalui Penerapan 8 Fungsi Keluarga. J-ABDIPAMAS (Jurnal Pengabdian Kepada Masyarakat), 2(1), 76-80.

Hisyam, M. R., Suyanto, S., Sadzili, M., Arifin, Z., \& Rahman, A. S. (2019). Peran Anggota Keluarga Berketahanan Dalam Perspektif Quran. Ulumuddin: Jurnal Ilmu-Ilmu Keislaman, 9(2), 171-186.

Kadi, T., \& Awwaliyah, R. (2017). Inovasi Pendidikan: Upaya Penyelesaian Problematika Pendidikan Di Indonesia. Jurnal Islam Nusantara, 1(2).

Khasinah, S. (2013). Hakikat Manusia Menurut Pandangan Islam Dan Barat. JURNAL ILMIAH DIDAKTIKA: Media Ilmiah Pendidikan Dan Pengajaran, 13(2).

Kosim, M. (2020). Penguatan Pendidikan Karakter di Era Industri 4.0: Optimalisasi Pendidikan Agama Islam di Sekolah. TADRIS: Jurnal Pendidikan Islam, 15(1), 88-107. 
Kosim, M., Samad, D., Nasution, I., Kustati, M., Rivauzi, A., \& Anidar, J. (2020). Cadre Model Inspirative Based on Islamic Parenting and Minangkabau Local Wisdom. International Conference On Social Studies, Globalisation And Technology (ICSSGT 2019), 354-362.

Langgulung, H. (2002). Peralihan paradigma dalam pendidikan Islam dan sains sosial. Gaya Media Pratama. Mastuti, R., Maulana, S., Iqbal, M., Faried, A. I., Arpan, A., Hasibuan, A. F. H., Wirapraja, A., Saputra, D. H., Sugianto, S., \& Jamaludin, J. (2020). TEACHING FROM HOME: dari Belajar Merdeka menuju Merdeka Belajar. Yayasan Kita Menulis.

Mustaghfiroh, S. (2020). Konsep "Merdeka Belajar" Perspektif Aliran Progresivisme John Dewey. Jurnal Studi Guru Dan Pembelajaran, 3(1), 141-147.

Nata, D. R. H. A. (2014). Perspektif islam tentang strategi pembelajaran. Kencana.

Priatmoko, S., \& Dzakiyyah, N. I. (2020). Relevansi Kampus Merdeka Terhadap Kompetensi Guru Era 4.0 dalam Perspektif Experiential Learning Theory. At-Thullab, 4(1), 1-15.

Ramayulis, I. P. I. (2008). Ilmu Pendidikan Islam. Kalam Mulia.

Suprayogo, I., \& Tobroni. (2001). Metodologi Penelitian Sosial-Agama. Remaja Rosdakarya. 